\title{
Öğretmen Adaylarının Sosyal Beceri Düzeylerinin Bazı Değişkenler Açısından İncelenmesi*
}

\section{Investigation of the Preservice Teachers' Social Skills in Terms of Some Variables}

\section{Kayhan BOZGÜN ${ }^{\star *}$}

\section{Serpil PEKDOĞAN ${ }^{* * *}$}

\begin{abstract}
Öz. Bu çalışma ile geleceğin öğretmenleri olarak öğrencilerinin gelişim alanlarından sorumlu olacak öğretmen adaylarının sosyal beceri düzeylerini etkileyen değişkenlerin belirlenmesi amaçlanmaktadır. Araştırma, nicel araştırma yöntemlerinden tarama deseni ile gerçekleştirilmiştir. Araştırmanın çalışma grubunu 628 öğretmen adayı oluşturmaktadır. Veri toplama aracı olarak, araştırmacılar tarafından hazırlanan kişisel bilgi formu ve Koydemir (2006) tarafından uyarlanan Sosyal Beceri Envanteri-Kısa Formu kullanılmıştır. Verilerin analizinde bağımsız örneklem t testi, tek yönlü varyans analizi (ANOVA) teknikleri kullanılmıştır. Çalışmanın ortaya çıkardı̆̆ı bulgulara göre, öğretmen adaylarının sosyal beceri düzeylerinin; cinsiyet, bölüm, sınıf, aile geliri, anne-baba birlikteliği değişkenlerine göre anlamlı bir farklılık gösterdiği belirlenmiştir. Öğretmen adaylarının sosyal beceri düzeylerinin; kardeş sayısı, doğum sırası, anne-baba yaşam durumu, anne-baba öz-üvey olma, anne-baba eğitim düzeyi değişkenlerine göre bir farklılık göstermediği sonucuna varılmıştır. Yapılacak benzer çalışmalarda araştırmacılara, öğretmen ve öğretmen adaylarının sosyal beceri konusundaki bilgi düzeylerinin belirlenmesi önerilebilir.
\end{abstract}

Anahtar Kelimeler: Sosyal beceri, öğretmen adayı, değişken, düzey.

Abstract. With this study, it is aimed to determine the variables affecting the social skill levels and social skill levels of the prospective teachers who will be responsible for the development areas of their students as future teachers. The research was carried out with survey method. The study group of the study is composed of 628 preservice teachers. Personal data form and Social Skill Inventory-Short Form were used as data collection tool. Independent sample $t$ test, ANOVA techniques were used in the analysis of the data. According to the findings of the study, it was concluded that the preservice teachers had a meaningful difference between the the social skill levels and variables of gender, department, class, family income, parents-to-parent. There is not significant difference between the number of siblings, the order of birth, parental life status, parents' self-esteem, parental education level and the social skill levels of preservice teachers. In similar studies to be done, it may be advisable to researchers to determine the level of knowledge about social skills of teachers and preservice teachers.

Keywords: Social skill, preservice teacher, variable, level.

\begin{abstract}
Toplumsal Mesaj.
Sosyal becerisi gelişmiş çocuklar, akranlarıyla hem sağlıklı ilişkiler kurabilir hem de ailesi, okuldaki öğretmenleri ve arkadaşlarına sosyal bir birey olduğunu kanıtlama imkanı verir. Geleceğin öğretmenleri olarak öğrencilerinin gelişim alanlarından sorumlu olacak öğretmen adaylarının sosyal beceri düzeylerini etkileyen değişkenlerin bilinmesi önem arz etmektedir.
\end{abstract}

\section{Public Interest Statement. \\ Children with high social skills can establish healthy relationships with their peers and also prove that they are a social individual to their school teachers and friends and their families. It is needed to know the social skill levels of teacher candidates because of the teacher candidates are responsible for all the development areas of the child.}

\footnotetext{
* Bu çalışma, "Öğretmen adaylarının çocukluk dönemi istismar yaşantıları ile sosyal beceri düzeylerinin bazı değişkenler açısından incelenmesi" başlıklı yüksek lisans tezinden türetilmiştir ve bir kısmı, 18-21 Mayıs 2017'de Kuşadası/AYDIN'da düzenlenen III. Uluslararası Eğitim ve Bilim Araştırmaları Konferansı'nda (ICRES) sözlü bildiri olarak sunulmuştur.

** Orcid ID: http://orcid.org/0000-0001-9239-2547, Arş. Gör., Amasya Üniversitesi, Temel Eğitim Bölümü, kayhanbozgun@gmail.com

*** Orcid ID: http://orcid.org/0000-0002-8442-354X, Dr. Öğr.Üyesi, Hitit Üniversitesi, Çocuk Gelişimi Bölümü, serpil4423@hotmail.com

Bozgün, K. ve Pekdoğan, S. (2018). Öğretmen Adaylarının Sosyal Beceri Düzeylerinin Bazı Değişkenler Açısından İncelenmesi. Sakarya University Journal of Education, 8(4), 151-167.
} 


\section{Gíriş}

Insanların mutlu, sağlıklı ve eğitimli olmaları toplumsal kalkınmanın temelini oluşturmaktadır. Duygusal, bilişsel ve sosyal gelişim dönemlerini sağlıklı şekilde geçiren bireyler toplumda daha başarılı ve mutlu olabilmektedir. Yaşadığı toplumda sevilmek, sevmek, kabul edilmek, iletişim kurmak gibi sosyal intiyaçları olan birey bu gereksinimlerini karşılayarak iyi ilişkiler geliştirmeyi amaçlar (Okumuş, 2011). Bu amacın gerçekleştirilmesi için sağlıklı bir sosyal gelişim döneminden geçmek önemlidir. Sosyal gelişim; yaş, cinsiyet, ailedeki doğum sırası, kardeş sayısı, aile geliri, arkadaş ilişkileri, anne-babanın çocuk yetiştirme tutumu gibi birçok değişkenden etkilenebilmektedir (Durualp, 2014).

Başkalarının ne hissettiğini, düşündügünü sezebilme becerisi bir ilişki kurmada sosyal açıdan iyi bir başlangıç sayılabilir; ancak bu beceri verimli bir etkileşim ortamı sağlamanın garantisini veremez. Pürüzsüz ve etkili ilişkiler kurmak için gerekli beceriler sosyal becerilerdir (Goleman, 2016). Kişilerarası iletişimin başarılı olmasının altında sosyal beceri faktörü yatar. Sosyal zekanın temel bileşenleri olan sosyal beceriler; kendini sosyal etkileşimler içinde ifade edebilme yeteneğini, farklı sosyal durumları "okumak" ve "anlamak" yeteneğini, sosyal roller bilgisini, normlar ve senaryoları, kişilerarası problem çözme becerilerini ve sosyal rol yapma becerilerini içerir (Riggio ve Reichard, 2008).

Sosyal beceriler, başkaları hakkındaki sezgilerimizi oluşturan sosyal farkındalığı kullanarak ne yaptığımız ile ilgilidir (Goleman, 2016). Bacanlı (2014), sosyal beceriyi, sosyal farkındalık ile kazanılan bilgilerden ziyade, diğer kişilerle etkililiği ve devamlılığı olan ilişkiler kurmaya yarayan bir süreç olarak tanımlar. Gresham (2016) ise sosyal becerileri, bir kişinin sergilediği belirli davranışlar sınıfı ve sosyal görevlerin başarıyla yerine getirilme becerisi olarak tanımlar. Burger (2006) sosyal beceriyi, iki veya daha çok kişinin aralarında eğlenceli ve anlamlı bir konuşma gerçekleştirme yetisi olarak tanımlamaktadır. Sosyal beceri düzeyini artırmanın en iyi yollarından biri başkalarıyla iletişim kurmaktan, geçmektedir. Gülay ve Akman (2009), sosyal becerilerin, bireyin etkileşimde bulunduğu ortamlarda olumlu dönütler almasını sağlayan, sosyal ilişkileri başlatan ve devam ettiren öğrenilmiş davranışlar olduğunu belirtmişlerdir. Meadan ve Monda-Amaya (2008) ise sosyal becerilerin, sosyal yeterlikle bütünleşebilen öğrenilen davranışlar olduğunu ifade etmiştir. Sosyal kabulü artıran sosyal beceriler, sosyal yeterliğin bir parçası olarak kabul edilmektedir. Bireyin sosyal gelişimini etkileyen sosyal beceri, sosyal yeterliği de kapsamına aldığı için sosyal yeterlik kazanımında gerekli olan davranışları da ifade etmelidir (Johns vd., 2005). Sosyal yeterliğin belirlenmesi için öncelikle sosyal becerilerin belirlenmesi gereklidir (Bacanlı, 2014). Sosyal yeterliğini kazanamayan bireyler; depresyon, kaygı, içe kapanıklık, akademik başarısızlık, okulu bırakma isteği, ailesi, akranları ve çevresindeki diğer insanlarla problem yaşama, şiddet, sigara bağımlılığı, olumsuz çatışma, düzensiz beslenme ve uyku alışkanlıkları gibi olumsuz durumlarla karşılaşabilmektedir (Burger, 2006; Burke, 2002; Gülay ve Akman, 2009).

Sosyal becerileri gelişmiş bir birey, çevresinde kabul gören, sevilen, popüler olan, arkadaş bulmakta güçlük çekmeyen, saldırgan davranışları olmayan, öfkesini kontrol edebilen, stresli durumlarla başa çıkabilen, sosyal problemleri çözmede başarılı olan kişidir (Gülay ve Akman, 2009). Çocuklardaki sosyal becerilerin gelişmesi ile saldırgan davranışlar azalır, aile ilişkileri güçlenir, sağlam akran ilişkileri kurulur, işbirliği ve paylaşma artar (Durualp, 2014). Sosyal becerilerin uygun eğitim programları kullanarak geliştirilebildiği, yapılan araştırmalarla da kanıtlanmıştır (Dereli-iman, 2014; Durualp ve Aral, 2010; Villares vd., 2008).

Sosyal beceri, çocukluk döneminde aile, okul ve arkadaş çevresinden kazanıldığı için öğretmenlerin bu becerilerin gelişmesinde büyük önemi bulunmaktadır (Berry ve O'Connor, 2010; Özabacı, 2004). Kasatura (1991) çocukların, sadece ders anlatıp öğretim yapan öğretmenler yerine; şakacı, anlayışlı, olgun, çocukların kişilik özelliklerinin farkında olan sosyal becerileri gelişmiş öğretmenler istediklerini ifade etmiştir (Aktaran; Tosuntaş-Karakuş, 2006). Ertuğrul (2011), öğrencileri ile güzel konuşan, iletişim yeteneği olan, öğrencilerini dışarıda da izleyen ve onları iyi tanıyan, davranış bozukluğu olan öğrencilerinin gelişimlerini takip eden, ev ziyaretleri yaparak öğrencisinin okul 
dışındaki gelişimini de takip eden öğretmenleri ideal ve tercih edilen öğretmenlerin nitelikleri olarak ifade etmiştir. Sosyal beceriler konusunda farkındalığı yüksek olan bir öğretmen, öğrencilerinin sorunlarını çözmesi için bu konuda öğrencilerine gerekli desteği verme ihtiyacı hisseder. Öğretmen destek vermediğinde, öğrenci, arkadaş ve aile ortamında nasıl davranacağını bilemeyerek, herhangi bir sosyal ortama da giremeyerek olumsuz hissedebilir (Dökmen, 2001).

Sosyal beceri unsurları birbiri ile ilişkili olduğundan dolayı, öğretmenler sosyal becerilerin tamamını kazanmış olmalıdır. Bu becerilerden birine ya da bazılarına sahip olmak öğretmen için yeterli olmayacaktır (Girgin vd., 2011). Öğretmenlerin kendilerini geliştirmesi, öğrencinin öğrenme düzeyini ve öğrenme kalıcılığını artırdığından dolayı öğretmenlerin genel kültür, alan bilgisi ve pedagojik donanımlarının üst seviyede olması gerekir (Dilekmen, 2008; Karacaoğlu, 2008). Öğretmen ve öğrenci arasında özel bir ilişki kurularak etkili olan öğrenme sürecinin öğretmenin sosyal becerilerine bağlı olduğu düşünüldüğünde yetiştirilecek öğretmen adaylarının da bu yönde becerilere sahip olmaları sağlanmalıdır (Tepeli ve Arı, 2011:387). Girgin ve diğerleri (2011), kazanılması gereken sosyal becerilerin alt boyutları birbiri ile ilişkili olduğu için öğretmenlerin her beceriyi kazanması gerektiğini ifade etmişlerdir. Bu becerileri kazanan öğretmenin nitelikleri incelendiğinde, öğrencisini benlik saygısını destekleyen, sözel olan ve olmayan mesajları alıp vermede öğrencisini dinleyen, ona değer veren, içsel motivasyonlarını destekleyen, işbirlikçi, derslerini öğrencilerin becerilerini geliştirecek şekilde tasarlayan bir öğretmen profili ile karşılaşıı (Jennings ve Greenberg, 2009; Yüksel, 2001). Öğretmenlerin sosyal becerileri kazanmamış olması, öğrencilerinin akademik başarılarının düşmesine ve olumsuz davranışlarının artmasına yol açmaktadır (Marzano, Marzano ve Pickering, 2003'ten aktaran; Jennings ve Greenberg, 2009). Sosyal becerileri yüksek öğretmenlerin özfarkındalık düzeyleri ve sosyal farkındalıkları yüksektir. Bu öğretmenler, sınıfta etkili bir sınıf yönetiminin yanı sıra, çatışma durumlarının çözümünde etkili iletişimi kullanmaları, farkı kültürel özellikleri bilen ve bu özellikleri aile, çocuklar ve iş arkadaşları ile kurduğu iletişime yansıtan nitelikleriyle, öğrencilerin bu davranışlardan pozitif etkilenmesini sağlarlar (Jennings ve Greenberg, 2009; Türkan vd., 2017). Gelişim dönemlerinin büyük bir kısmını da okulda geçiren çocukların sağlıklı gelişimi için öğretmenin de çocukların bütüncül gelişimine önem vermesi gerekmektedir. Çocuğun bilişsel, sosyal ve duygusal gelişimlerinde de büyük katkısı olacak olan öğretmen adaylarının çocuklarla sağlıklı ilişkiler geliştirmesi için sosyal becerileri kazanmış olmanın ihtiyacı anlaşıımış olacaktır. Öğretmen adaylarının meslek hayatına başladıklarında, öğrencilere sadece eğitim vermekle kalmayıp onları tanımak, gelişimsel özelliklerinin bilincinde olmak ve çocukların yaşadığı sorunları görmezden gelmeyerek çocuklara yardımcı olmaları gerekmektedir. Sosyal becerilerin belirlenmesi ile sağlıklı gelişimde rol oynayan faktörlerin bilincinde olacak olan öğretmen adayları, sağlıklı bir nesil yetiştirmek için de önemli bir görev üstlenebileceklerdir.

Çocukların sosyal becerileri kazanmasında rolleri büyük olan öğretmenlerin ve öğretmen adaylarının sahip olması gereken niteliklerin sınırlı olmadığı, yapılan çalışmalardan anlaşılmaktadır. Sosyal beceri düzeylerinin ele alındığı yurtdışı kökenli çalışmalarda öğrenci, aile ve öğretmenlerin etkileşimine bağlı olarak sosyal becerilerin gelişimini inceleyen çalışmalara ağırlık verilmiştir. Bu çalışmaların arasında çocukların ve öğrencilerin sosyal becerilerini inceleyen (Anthony vd., 2016; Gresham, 2016; Griffith vd., 2016; Riney ve Bullock, 2012); öğretmenlerin sosyal beceri gelişimlerini inceleyen (Berry ve Connor, 2010; Burke vd., 2012; Tynjälä vd., 2016; Väyrynen vd., 2016) çalışmalar yer almaktadır. Öğretmen adaylarının sosyal beceri düzeylerini farklı değişkenler açısından incelemeyi amaçlayan ulusal düzeyde çalışmalar da mevcuttur (Girgin vd., 2011; Kozağaç, 2015; S. Akpınar vd., 2015; Seven ve Yoldaş, 2007; Ş. Akpınar, 2014; Şenol ve Türkçapar, 2016; Türkan vd., 2017; Yaşar-Ekici, 2017; Yazıcı, 2016; Zengin vd., 2012).

ilgili çalışmalarda kullanılan değişkenlerin bir araya getirildiği bu çalışma ile alanyazına farkı bir bakış açısı kazandırmak ve öğretmen adaylarının sosyal beceriler ile ilgili farkındalıklarının artması beklenmektedir. Sosyal becerisi gelişmiş bir öğretmenin, sınıftaki atmosfere olumlu etkileri göz 
önüne alındığında, yapılması gereken, öğretmenlerin ve öğretmen adaylarının sosyal becerilerini etkileyen değişkenleri belirlemektir (Seven ve Yoldaş, 2007).

Ayrıca, bu çalışma ile bu konuda yapılacak çalışmalara ve alınacak önlemlere rehber olunacağı varsayılmaktadır.

\subsection{Amaç}

Bu araştırmanın genel amacı, öğretmen adaylarının sosyal beceri düzeyleri ile aralarında anlamlı farklılık bulunan bazı değişkenleri belirlemektir. Bu çalışmanın temel problemini, "Cinsiyet, okuduğu bölüm, sınıf düzeyi, aile gelir düzeyi, anne-babanın birlikteliği değişkenleri ile öğretmen adaylarının sosyal beceri düzeyleri arasında anlamlı farklıık var mıdır?" sorusu teşkil etmektedir.

\section{YÖNTEM}

Bu araştırma öğretmen adaylarının sosyal beceri düzeylerinin bazı değişkenler açısından belirlenmesi amaçlandığından, nicel araştırma yöntemlerinden betimsel tarama modeli kullanılmıştır. Tarama modeli, diğer araştırma desenlerine göre daha geniş örneklemler ile çalışılmasına olanak tanıyan, ölçülmek istenen özelliğin hangi düzeyde olduğunu belirlemek için tercih edilir (Büyüköztürk vd., 2013).

\subsection{Evren-Örneklem}

Araştırmanın evreni, Amasya Üniversitesi Eğitim Fakültesi'nde 2016-2017 eğitim-öğretim yılının güz döneminde, Fen Bilgisi Öğretmenliği (FEN), Sınıf Eğitimi (SINIF), Okul Öncesi Eğitimi Öğretmenliği (OKÖ) ve Rehberlik-Psikolojik Danışmanlık (RPD) bölümlerinde öğrenim gören tüm öğrenciler; örneklemi ise bu evrenin birinci, ikinci, üçüncü ve dördüncü sınıflarından rastgele seçilen birer şubesinde öğrenimlerine devam eden 628 öğretmen adayıdır. Çalışma grubunu belirlemek için verilerin toplanacağı birimlerin eşit seçilme şansına sahip olduğu bir örnekleme türü olan basit tesadüfi örnekleme yöntemi kullanıımıştır (Şahin, 2011).

\subsection{Veri Toplama Yöntemi}

Kişisel Bilgi Formu: Bu form, öğretmen adaylarının sosyal beceri düzeylerinin; cinsiyet, devam ettiği lisans programı, lisans programındaki sınıf düzeyi, aile geliri, anne-baba birlikteliği hakkında bilgi edinmek için araştırmacılar tarafından hazırlanmıştır.

Sosyal Beceri Envanteri Kısa Formu (SBE-KF): SBE-KF adında özgün ölçeğin 30 maddelik kısa formunu Koydemir (2006) hazırlamıştır. Bu kısa form hazırlanırken, 90 maddelik orijinal ölçeğin (Riggio, 1986:649) Türkçeye uyarlamasını yapan Yüksel'in (1997:55) Türkçe formundaki maddelerden yararlanılmıştır. SBE-KF beşli likert kategoriye sahiptir. SBE-KF'den alınabilecek en düşük puan 30 iken; en yüksek puan 150'dir. Ölçeğin "duyuşsal anlatımcılık, duyuşsal duyarlık, duyuşsal control, sosyal anlatımcılık, sosyal duyarlık ve sosyal kontrol" olmak üzere altı alt faktörü bulunmaktadır. Ölçekten alınan puanların yükselmesi bireyin genel sosyal beceri düzeyinin artması olarak tanımlanmaktadır. Koydemir (2006:75), SBE-KF ölçeğinin genelinden elde etmiş olduğu Cronbach alfa değerini .70 olarak ve ölçeğin faktör analizi sonuçlarına göre altı faktör ve 30 maddeden oluşan bir ölçek olduğunu belirleyerek SBE-KF için yeteri düzeyde geçerlik ve güvenirliğe sahip bir ölçme aracı tanımlaması yapmıştır (Şahin ve Gizir, 2013:148). Bu çalışmanın veri setindeki öğretmen adaylarının sosyal beceri envanteri verilerinin Cronbach alfa güvenirlik katsayısı .71 olarak belirlenmiştir. Koydemir'in (2006) öğretmen adayları ile çalışması da ölçeğin ve bu çalışmadaki örneklem grubunun bu araştırma ile uyumlu olduğunu gösterir niteliktedir.

\subsection{Verilerin Analizi}

Verilerin analizinde SPSS: Statistical Package for the Social Sciences paket programı kullanılmıştır. Bu çalışmadaki, Kolmogorov-Smirnow, çarpıklık katsayıları ve basıklık değerleri birlikte göz önüne alındığında SBE-KF verilerinin normal dağıldığı ( $p>$.05) saptanmıştır. Normal dağılımlar için parametrik testlerden bağımsız örneklem $t$ testi (independent sample $t$ test), frekans, yüzde dağılımları, tek yönlü varyans analizi (One-way Anova) kullanılmıştır (Büyüköztürk, 2013:39). 
Normal dağılım gösteren verilerde üç ve daha çok sayıdaki gruplar için kullanılan tek yönlü varyans analizi (ANOVA) sonrasında değişkenlerin alt grupları arasında farklılık olup olmadığını anlamak için tamamlayıcı post-hoc analiz tekniklerinden LSD ve Tukey-HSD testleri uygulanmıştır. Bu araştırmada iki tür (.01 ve .05) anlamlııık düzeyi baz alınmıştır.

\section{BULGULAR}

Öğretmen adaylarının sosyal becerilerinin cinsiyete göre farklılaşıp farklılaşmadığını belirlemek için gerçekleştirilen bağımsız örneklemler $t$ testi sonuçları Tablo 1'de verilmiştir.

Tablo 1. Cinsiyete Göre Sosyal Beceri Düzeyi $t$ Testi

\begin{tabular}{|c|c|c|c|c|c|c|c|}
\hline \multirow{2}{*}{ Puan } & \multirow{2}{*}{ Cinsiyet } & \multirow{2}{*}{$n$} & \multirow{2}{*}{$\bar{X}$} & \multirow{2}{*}{ SS } & \multicolumn{3}{|c|}{$t$ Testi } \\
\hline & & & & & $t$ & $s d$ & $p$ \\
\hline \multirow{2}{*}{ DA } & Erkek & 151 & 15.52 & 3.33 & \multirow{2}{*}{2.88} & \multirow{2}{*}{626} & \multirow{2}{*}{$.004 * *$} \\
\hline & Kadın & 477 & 16.40 & 3.30 & & & \\
\hline \multirow{2}{*}{ DD } & Erkek & 151 & 18.46 & 3.71 & \multirow{2}{*}{-1.91} & \multirow{2}{*}{626} & \multirow{2}{*}{.06} \\
\hline & Kadın & 477 & 17.78 & 3.84 & & & \\
\hline \multirow{2}{*}{ DK } & Erkek & 151 & 15.83 & 2.87 & \multirow{2}{*}{-5.06} & \multirow{2}{*}{626} & \multirow{2}{*}{$.001 * *$} \\
\hline & Kadın & 477 & 14.44 & 2.96 & & & \\
\hline \multirow{2}{*}{ SA } & Erkek & 151 & 16.20 & 4.77 & \multirow{2}{*}{-1.57} & \multirow{2}{*}{626} & \multirow{2}{*}{.12} \\
\hline & Kadın & 477 & 15.54 & 4.37 & & & \\
\hline \multirow{2}{*}{ SD } & Erkek & 151 & 15.27 & 4.20 & \multirow{2}{*}{-1.61} & \multirow{2}{*}{626} & \multirow{2}{*}{11.} \\
\hline & Kadın & 477 & 14.64 & 4.19 & & & \\
\hline \multirow{2}{*}{ SK } & Erkek & 151 & 16.76 & 3.21 & \multirow{2}{*}{-1.70} & \multirow{2}{*}{626} & \multirow{2}{*}{.09} \\
\hline & Kadın & 477 & 16.25 & 3.17 & & & \\
\hline \multirow[t]{2}{*}{ SBTP } & Erkek & 151 & 98.03 & 11.52 & \multirow{2}{*}{-2.89} & \multirow{2}{*}{626} & \multirow{2}{*}{$.004 * *$} \\
\hline & Kadın & 477 & 95.05 & 10.85 & & & \\
\hline
\end{tabular}

Not: $p<.01^{\star \star}$. (DA: Duyuşsal Anlatımcılık; DD: Duyuşsal Duyarlık; DK: Duyuşsal Kontrol; SA: Sosyal Anlatımcılık; SD: Sosyal Duyarlık; SK: Sosyal Kontrol; SBTP: Sosyal Beceri Toplam Puanı)

Tablo 1'de görüldüğü gibi, duyuşsal anlatımcılık [t(626)=2.878; $p<.01]$, duyuşsal kontrol $[t(626)=5.061 ; p<.01]$ alt faktörlerinde ve SBE-KF toplam puanında $[t(626)=2.890 ; p<.01]$ öğretmen adaylarının cinsiyetlerine göre anlamlı fark olduğu ortaya çıkmıştır. Bu fark ortalama puanlar açısından, duyuşsal anlatımcılık boyutunda kadın öğrencilerin lehine $(\bar{X}=16.40)$ iken; duyuşsal kontrol $(\bar{X}=15.83)$ ve SBE-KF'nin toplam puanında $(\bar{X}=98.03)$ erkek öğrencilerin lehine olarak belirlenmiştir. Duyuşsal duyarlık $(\bar{X}=18.46)$, sosyal anlatımcılık $(\bar{X}=16.20)$, sosyal duyarlık $(\bar{X}=15.27)$ ve sosyal kontrol $(\bar{X}=16.76)$ alt boyutunda erkek öğretmen adayları lehine görünen farklılı̆ın ise anlamlı olmadığı görülmektedir.

Öğretmen adaylarının eğitim aldıkları bölüm türüne göre sosyal beceri düzeyleri puanlarının aritmetik ortalama ve standart sapma değerleri ile tek yönlü ANOVA sonuçları Tablo 2'de görülmektedir. 
Tablo 2. Bölümlere Göre Sosyal Beceri Düzeyi Tek Yönlü ANOVA Sonuçları

\begin{tabular}{|c|c|c|c|c|c|c|c|c|}
\hline Puan & Bölüm & $n$ & $\overline{\bar{X}}$ & SS & $s d_{1}, s d_{2}$ & $F$ & $p$ & İşlem Sonrası \\
\hline \multirow{5}{*}{ DA } & FEN & 157 & 15.73 & 3.41 & & \multirow{5}{*}{1.63} & \multirow{5}{*}{.182} & \\
\hline & SINIF & 165 & 16.19 & 3.19 & 3,624 & & & \\
\hline & OKÖ & 150 & 16.33 & 3.27 & & & & \\
\hline & RPD & 156 & 16.52 & 3.40 & & & & \\
\hline & Toplam & 628 & 16.19 & 3.32 & & & & \\
\hline \multirow{5}{*}{ DD } & FEN & 157 & 18.53 & 3.67 & & \multirow{5}{*}{2.47} & \multirow{5}{*}{.061} & \\
\hline & SINIF & 165 & 18.07 & 4.07 & 3,624 & & & \\
\hline & OKÖ & 150 & 17.71 & 3.66 & & & & \\
\hline & RPD & 156 & 17.43 & 3.79 & & & & \\
\hline & Toplam & 628 & 17.94 & 3.82 & & & & \\
\hline \multirow{5}{*}{ DK } & FEN & 157 & 15.11 & 2.89 & & \multirow{5}{*}{4.68} & \multirow{5}{*}{$.003 * \star$} & \multirow{5}{*}{$\begin{array}{l}\text { FEN-OKÖ } \\
\text { SINIF-OKÖ }\end{array}$} \\
\hline & SINIF & 165 & 15.27 & 3.06 & 3,624 & & & \\
\hline & OKÖ & 150 & 14.18 & 3.07 & & & & \\
\hline & RPD & 156 & 14.48 & 2.86 & & & & \\
\hline & Toplam & 628 & 14.77 & 3.00 & & & & \\
\hline \multirow{5}{*}{ SA } & FEN & 157 & 16.34 & 4.50 & & \multirow{5}{*}{5.03} & \multirow{5}{*}{$.002^{* \star}$} & \multirow{5}{*}{$\begin{array}{l}\text { FEN-RPD } \\
\text { SINIF-RPD }\end{array}$} \\
\hline & SINIF & 165 & 16.37 & 4.48 & 3,624 & & & \\
\hline & OKÖ & 150 & 15.21 & 4.06 & & & & \\
\hline & RPD & 156 & 14.82 & 4.64 & & & & \\
\hline & Toplam & 628 & 15.70 & 4.47 & & & & \\
\hline \multirow{5}{*}{ SD } & FEN & 157 & 14.81 & 4.47 & & \multirow{5}{*}{1.21} & \multirow{5}{*}{.304} & \\
\hline & SINIF & 165 & 15.28 & 4.23 & 3,624 & & & \\
\hline & OKÖ & 150 & 14.49 & 4.05 & & & & \\
\hline & RPD & 156 & 14.54 & 4.01 & & & & \\
\hline & Toplam & 628 & 14.79 & 4.20 & & & & \\
\hline \multirow{5}{*}{ SK } & FEN & 157 & 16.90 & 3.05 & & \multirow{5}{*}{3.40} & \multirow{5}{*}{$.018 *$} & \multirow{5}{*}{ FEN-RPD } \\
\hline & SINIF & 165 & 16.55 & 3.10 & 3,624 & & & \\
\hline & OKÖ & 150 & 16.19 & 3.34 & & & & \\
\hline & RPD & 156 & 15.82 & 3.18 & & & & \\
\hline & Toplam & 628 & 16.37 & 3.18 & & & & \\
\hline \multirow{5}{*}{$\begin{array}{l}\text { SB } \\
\mathrm{TP}\end{array}$} & FEN & 157 & 97.43 & 10.60 & & \multirow{5}{*}{6.18} & \multirow{5}{*}{$.001 * \star$} & \multirow{5}{*}{$\begin{array}{l}\text { FEN-OKÖ } \\
\text { SINIF-OKÖ } \\
\text { FEN-RPD } \\
\text { SINIF-RPD }\end{array}$} \\
\hline & SINIF & 165 & 97.74 & 11.08 & 3,624 & & & \\
\hline & OKÖ & 150 & 94.11 & 10.45 & & & & \\
\hline & RPD & 156 & 93.61 & 11.57 & & & & \\
\hline & Toplam & 628 & 95.77 & 11.08 & & & & \\
\hline
\end{tabular}

Not: $p<.05^{*}, p<.01^{\star *}$.

Tablo 2'de öğretmen adaylarının bölümlerine göre sosyal beceri ortalamalarına ilişkin gerçekleştirilen tek yönlü ANOVA sonucunda, bölümler ile duyuşsal kontrol $[F(3,624)=4.68 ; p<.01]$, sosyal anlatım $[F(3,624)=5.03 ; p<.01]$ ve sosyal kontrol $[F(3,624)=3.40 ; p<.05]$ alt boyutları ile 
birlikte SBE-KF toplam puanları $[F(3,624)=6.18 ; p<.001]$ arasında anlamlı bir farklılığın olduğu görülmektedir. Farklılı̆ıı kaynağını belirleyebilmek için gerçekleştirilen işlem sonrası Tukey HSD testi sonucunda öğretmen adaylarının bölümlerinden duyuşsal kontrol alt boyutunda FEN $(\bar{X}=15.11)$ ve SINIF'ın $(\bar{X}=15.27)$ OKÖ'den $(\bar{X}=14.82)$; sosyal anlatımcilık alt boyutunda FEN $(\bar{X}=16.34)$ ve SINIF'In $(\bar{X}=16.37)$ RPD'den $(\bar{X}=15.11)$; sosyal kontrol alt boyutunda FEN'in $(\bar{X}=16.90)$ RPD'den $(\bar{X}=15.82)$ anlamlı bir şekilde yüksek olduğu bulunmuştur. Aynı zamanda SBEKF toplam puanında FEN ( $\bar{X}=97.43)$ ve SINIF'ın $(\bar{X}=97.74)$ OKÖ $(\bar{X}=94.11)$ ve RPD'den $(\bar{X}=93.61)$ anlamlı bir şekilde yüksek olduğu bulunmuştur. Diğer alt boyutlardaki gruplar arasında anlamlı bir puan farklıı̆̆ının olmadığı bulunmuştur.

Öğretmen adaylarının sınıflarına göre sosyal beceri düzeyleri puanlarının aritmetik ortalama ve standart sapma değerleri ile tek yönlü ANOVA sonuçları Tablo 3'te görülmektedir.

Tablo 3. Sınıflara Göre Sosyal Beceri Düzeyi Tek Yönlü ANOVA Sonuçları

\begin{tabular}{|c|c|c|c|c|c|c|c|c|}
\hline Puan & Sinıf & $n$ & $\bar{X}$ & ss & $s d_{1}, s d_{2}$ & $F$ & $p$ & İşlem Sonras \\
\hline \multirow{5}{*}{ DA } & 1 & 153 & 16.17 & 3.37 & \multirow{5}{*}{3,624} & \multirow{5}{*}{.51} & \multirow{5}{*}{.677} & \\
\hline & 2 & 150 & 16.11 & 3.34 & & & & \\
\hline & 3 & 170 & 16.44 & 3.33 & & & & \\
\hline & 4 & 155 & 16.07 & 3.27 & & & & \\
\hline & Toplam & 628 & 16.19 & 3.32 & & & & \\
\hline \multirow{5}{*}{ DD } & 1 & 153 & 17.86 & 4.17 & \multirow{5}{*}{3,624} & \multirow{5}{*}{.50} & \multirow{5}{*}{.684} & \\
\hline & 2 & 150 & 18.27 & 3.36 & & & & \\
\hline & 3 & 170 & 17.83 & 3.76 & & & & \\
\hline & 4 & 155 & 17.82 & 3.95 & & & & \\
\hline & Toplam & 628 & 17.94 & 3.82 & & & & \\
\hline \multirow{5}{*}{ DK } & 1 & 153 & 14.92 & 3.33 & \multirow{5}{*}{3,624} & \multirow{5}{*}{.37} & \multirow{5}{*}{.776} & \\
\hline & 2 & 150 & 14.57 & 2.93 & & & & \\
\hline & 3 & 170 & 14.80 & 3.01 & & & & \\
\hline & 4 & 155 & 14.79 & 2.69 & & & & \\
\hline & Toplam & 628 & 14.77 & 3.00 & & & & \\
\hline \multirow{5}{*}{ SA } & 1 & 153 & 15.20 & 4.73 & \multirow{5}{*}{3,624} & \multirow{5}{*}{3.31} & \multirow{5}{*}{$.020 *$} & \multirow{5}{*}{$3-2$} \\
\hline & 2 & 150 & 15.09 & 4.48 & & & & \\
\hline & 3 & 170 & 16.42 & 4.24 & & & & \\
\hline & 4 & 155 & 15.99 & 4.35 & & & & \\
\hline & Toplam & 628 & 15.70 & 4.47 & & & & \\
\hline \multirow{5}{*}{ SD } & 1 & 153 & 15.12 & 4.61 & \multirow{5}{*}{3,624} & \multirow{5}{*}{1.24} & \multirow{5}{*}{.294} & \\
\hline & 2 & 150 & 15.13 & 4.04 & & & & \\
\hline & 3 & 170 & 14.55 & 3.74 & & & & \\
\hline & 4 & 155 & 14.41 & 4.38 & & & & \\
\hline & Toplam & 628 & 14.79 & 4.20 & & & & \\
\hline \multirow{5}{*}{ SK } & 1 & 153 & 16.18 & 3.27 & \multirow{5}{*}{3,624} & \multirow{5}{*}{2.29} & \multirow{5}{*}{.078} & \\
\hline & 2 & 150 & 16.05 & 3.32 & & & & \\
\hline & 3 & 170 & 16.90 & 2.95 & & & & \\
\hline & 4 & 155 & 16.29 & 3.18 & & & & \\
\hline & Toplam & 628 & 16.37 & 3.18 & & & & \\
\hline
\end{tabular}




\begin{tabular}{llllllll}
\hline SB & 1 & 153 & 95.46 & 11.91 & & & \\
TP & 2 & 150 & 95.22 & 10.92 & & & \\
& 3 & 170 & 96.95 & 9.93 & 3,624 & .89 & .446 \\
& 4 & 155 & 95.32 & 11.57 & & & \\
& Toplam & 628 & 95.77 & 11.08 & & \\
\end{tabular}

Not: $p<.05^{*}$.

Tablo 3'te, gerçekleştirilen tek yönlü ANOVA sonucunda öğretmen adaylarının sınıf seviyeleri ile sosyal anlatımcılık alt boyutu arasında anlamlı bir fark olduğu görülmektedir $(F(3,624)=3.31 ; p<.05)$. Farklıı̆ı̆ın kaynağını belirleyebilmek için gerçekleştirilen işlem sonrası Tukey HSD testi sonucunda 3. sınıflardaki $(\bar{X}=16.42)$ öğretmen adaylarının sosyal beceri puanlarının, 2 . sınıflardaki $(\bar{X}=15.09)$ öğretmen adaylarından anlamlı bir şekilde yüksek olduğu belirlenmiştir. Diğer sınıflarda anlamlı bir farklııı̆̆ın olmadığı görülmüştür.

Öğretmen adaylarının aile geliri değişkenine göre sosyal beceri düzeyleri puanlarının aritmetik ortalama ve standart sapma değerleri ile tek yönlü ANOVA sonuçları Tablo 4'te görülmektedir.

Tablo 4. Aile Gelir Düzeyine Göre Sosyal Beceri Düzeyi Tek Yönlü ANOVA Sonuçları

\begin{tabular}{|c|c|c|c|c|c|c|c|c|}
\hline Puan & Aile Gelir Düzeyi & $n$ & $\overline{\bar{X}}$ & $s s$ & $s d_{1}, s d_{2}$ & $\bar{F}$ & $p$ & işlem Sonrası \\
\hline \multirow{7}{*}{ DA } & A. $0-1000 \mathrm{TL}$ & 122 & 16.02 & 3.35 & \multirow{7}{*}{5,622} & \multirow{7}{*}{.73} & \multirow{7}{*}{.603} & \\
\hline & B. $1001-2000 \mathrm{TL}$ & 247 & 16.26 & 3.44 & & & & \\
\hline & C. $2001-3000 \mathrm{TL}$ & 139 & 15.95 & 3.21 & & & & \\
\hline & D. $3001-4000 \mathrm{TL}$ & 82 & 16.43 & 3.14 & & & & \\
\hline & E. 4001-5000 TL & 20 & 17.25 & 2.94 & & & & \\
\hline & F. 5000 TL üstü & 18 & 16.06 & 3.65 & & & & \\
\hline & Toplam & 628 & 16.19 & 3.32 & & & & \\
\hline \multirow{7}{*}{$\mathrm{DD}$} & A. $0-1000 \mathrm{TL}$ & 122 & 18.02 & 3.77 & \multirow{7}{*}{5,622} & \multirow{7}{*}{2.24} & \multirow{7}{*}{$.049 *$} & \\
\hline & B. $1001-2000 \mathrm{TL}$ & 247 & 17.55 & 3.63 & & & & $C-B$ \\
\hline & C. $2001-3000 \mathrm{TL}$ & 139 & 18.43 & 3.95 & & & & $C-B$ \\
\hline & D. $3001-4000 \mathrm{TL}$ & 82 & 17.71 & 4.07 & & & & $F-B$ \\
\hline & E. 4001-5000 TL & 20 & 17.90 & 3.84 & & & & \\
\hline & F. 5000 TL üstü & 18 & 20.11 & 3.69 & & & & F-D \\
\hline & Toplam & 628 & 17.94 & 3.82 & & & & \\
\hline \multirow{7}{*}{ DK } & A. $0-1000 \mathrm{TL}$ & 122 & 14.90 & 3.00 & \multirow{7}{*}{5,622} & \multirow{7}{*}{.42} & \multirow{7}{*}{.832} & \\
\hline & B. $1001-2000 \mathrm{TL}$ & 247 & 14.67 & 3.05 & & & & \\
\hline & C. $2001-3000 \mathrm{TL}$ & 139 & 14.70 & 2.93 & & & & \\
\hline & D. $3001-4000 \mathrm{TL}$ & 82 & 14.98 & 2.82 & & & & \\
\hline & E. 4001-5000 TL & 20 & 14.35 & 3.23 & & & & \\
\hline & F. 5000 TL üstü & 18 & 15.39 & 3.48 & & & & \\
\hline & Toplam & 628 & 14.77 & 3.00 & & & & \\
\hline \multirow{7}{*}{ SA } & A. $0-1000 \mathrm{TL}$ & 122 & 15.06 & 4.59 & \multirow{7}{*}{5,622} & \multirow{7}{*}{3.65} & \multirow{7}{*}{$.003 * *$} & \\
\hline & B. $1001-2000 \mathrm{TL}$ & 247 & 15.62 & 4.38 & & & & \\
\hline & C. $2001-3000 \mathrm{TL}$ & 139 & 16.11 & 4.26 & & & & F-A \\
\hline & D. $3001-4000 \mathrm{TL}$ & 82 & 15.21 & 4.51 & & & & F-B \\
\hline & E. $4001-5000 \mathrm{TL}$ & 20 & 16.40 & 5.06 & & & & F-D \\
\hline & F. 5000 TL üstü & 18 & 19.44 & 4.09 & & & & \\
\hline & Toplam & 628 & 15.70 & 4.47 & & & & \\
\hline
\end{tabular}




\begin{tabular}{|c|c|c|c|c|c|c|c|c|}
\hline \multirow{7}{*}{ SD } & A. $0-1000 \mathrm{TL}$ & 122 & 15.34 & 4.56 & \multirow{7}{*}{5,622} & \multirow{7}{*}{1.04} & \multirow{7}{*}{.395} & \\
\hline & B. $1001-2000 \mathrm{TL}$ & 247 & 14.72 & 4.10 & & & & \\
\hline & C. $2001-3000 \mathrm{TL}$ & 139 & 14.55 & 3.94 & & & & \\
\hline & D. $3001-4000 \mathrm{TL}$ & 82 & 14.33 & 4.36 & & & & \\
\hline & E. 4001-5000 TL & 20 & 15.95 & 4.85 & & & & \\
\hline & F. 5000 TL üstü & 18 & 14.78 & 3.28 & & & & \\
\hline & Toplam & 628 & 14.79 & 4.20 & & & & \\
\hline \multirow{7}{*}{ SK } & A. $0-1000 \mathrm{TL}$ & 122 & 16.11 & 3.34 & \multirow{7}{*}{5,622} & \multirow{7}{*}{1.92} & \multirow{7}{*}{.089} & \\
\hline & B. $1001-2000 \mathrm{TL}$ & 247 & 16.38 & 3.14 & & & & \\
\hline & C. $2001-3000 \mathrm{TL}$ & 139 & 16.45 & 3.17 & & & & \\
\hline & D. 3001-4000 TL & 82 & 16.12 & 2.83 & & & & \\
\hline & E. 4001-5000 TL & 20 & 16.55 & 3.46 & & & & \\
\hline & F. 5000 TL üstü & 18 & 18.50 & 3.54 & & & & \\
\hline & Toplam & 628 & 16.37 & 3.18 & & & & \\
\hline \multirow{7}{*}{$\begin{array}{l}\text { SB } \\
\text { TP }\end{array}$} & A. $0-1000 \mathrm{TL}$ & 122 & 95.46 & 12.12 & \multirow{7}{*}{5,622} & \multirow{7}{*}{2.72} & \multirow{7}{*}{$.019 *$} & \multirow{7}{*}{$\begin{array}{l}\text { F-A } \\
\text { F-B } \\
\text { F-C } \\
\text { F-D }\end{array}$} \\
\hline & B. $1001-2000 \mathrm{TL}$ & 247 & 95.19 & 10.82 & & & & \\
\hline & C. 2001-3000 TL & 139 & 96.19 & 10.58 & & & & \\
\hline & D. 3001-4000 TL & 82 & 94.77 & 10.30 & & & & \\
\hline & E. 4001-5000 TL & 20 & 98.40 & 12.08 & & & & \\
\hline & F. 5000 TL üstü & 18 & 104.28 & 10.50 & & & & \\
\hline & Toplam & 628 & 95.77 & 11.08 & & & & \\
\hline
\end{tabular}

Not: $p<.05^{\star}, p<.01^{\star \star}$.

Tablo 4'te öğretmen adaylarının aile gelir düzeylerine göre sosyal beceri ortalamalarına ilişkin gerçekleştirilen tek yönlü ANOVA sonucunda, aile gelir düzeyleri ile duyuşsal duyarlık $[F(5,622)=3.395 ; p<.05]$, sosyal anlatımcllık $[F(5,622)=3.646 ; p<.01]$ ve SBE-KF toplam puanı $[F(5,622)=2.715 ; p<.05]$ ortalamaları arasında anlamlı bir farklıı̆̆ın olduğu görülmüştür. Farklılı̆ın kaynağını belirleyebilmek için gerçekleştirilen işlem sonrası Tukey HSD ve LSD testleri sonucunda öğretmen adaylarının aile gelir düzeylerinin duyuşsal duyarlık alt boyutunda 2001-3000 TL aile geliri ( $\bar{X}=18.43$ ) olanların 1001-2000 TL aile geliri $(\bar{X}=17.55)$ olanlardan; $5001 \mathrm{TL}$ ve fazlası aile geliri olanların $(\bar{X}=20.11)$ 0-1000 TL $(\bar{X}=18.02), 1001-2000$ TL $(\bar{X}=17.55)$ ve 3001-4000 TL $(\bar{X}=17.71)$ olanlardan anlamlı bir şekilde yüksek olduğu görülmüştür. Aynı zamanda sosyal anlatımcılık alt boyutunda, $5001 \mathrm{TL}$ ve fazlası aile geliri olanların ( $\bar{X}=19.44)$ 0-1000 TL $(\bar{X}=15.06), 1001-2000 \mathrm{TL}$ $(\bar{X}=15.62)$ ve 3001-4000 TL $(\bar{X}=15.21)$ olanlardan anlamlı bir şekilde sosyal beceri puanlarının yüksek olduğu belirlenmiştir. SBE-KF toplam puanında ise, 5001 TL ve fazlası aile geliri olanların $(\bar{X}=104.28), 0-1000$ TL $(\bar{X}=95.46), 1001-2000$ TL $(\bar{X}=95.19), 2001-3000$ TL $(\bar{X}=96.19)$ ve 3001-4000 $\mathrm{TL}(\bar{X}=94.77)$ olanlardan anlamlı bir şekilde sosyal beceri puanlarının yüksek olduğu görülmüştür. Diğer gruplar arasında anlamlı bir farklılığın olmadığı görülmüştür.

Öğretmen adaylarının anne-baba birlikteliği değişkenine göre sosyal beceri düzeyleri puanlarının aritmetik ortalama ve standart sapma değerleri ile tek yönlü ANOVA sonuçları Tablo 5'te görülmektedir. 
Tablo 5. Anne-Baba Birlikteliğine Göre Sosyal Beceri Düzeyi $t$ Testi Sonuçları

\begin{tabular}{|c|c|c|c|c|c|c|c|}
\hline \multirow{2}{*}{ Puan } & \multirow{2}{*}{$\begin{array}{l}\text { Anne-Baba } \\
\text { Birlikteliği }\end{array}$} & \multirow{2}{*}{$n$} & \multirow{2}{*}{$\bar{X}$} & \multirow{2}{*}{ SS } & \multicolumn{3}{|c|}{$t$ Testi } \\
\hline & & & & & $t$ & $s d$ & $p$ \\
\hline \multirow{2}{*}{ DA } & Birlikte & 583 & 16.20 & 3.33 & \multirow{2}{*}{-1.48} & \multirow{2}{*}{597} & \multirow{2}{*}{.140} \\
\hline & Ayrı & 16 & 17.44 & 2.42 & & & \\
\hline \multirow{2}{*}{ DD } & Birlikte & 583 & 17.92 & 3.79 & \multirow{2}{*}{-1.72} & \multirow{2}{*}{597} & \multirow{2}{*}{.086} \\
\hline & Ayrı & 16 & 19.56 & 3.54 & & & \\
\hline \multirow{2}{*}{ DK } & Birlikte & 583 & 14.78 & 3.03 & \multirow{2}{*}{-.19} & \multirow{2}{*}{597} & \multirow{2}{*}{.851} \\
\hline & Ayrı & 16 & 14.87 & 1.96 & & & \\
\hline \multirow{2}{*}{ SA } & Birlikte & 583 & 15.67 & 4.47 & \multirow{2}{*}{-2.44} & \multirow{2}{*}{597} & \multirow{2}{*}{$.015^{*}$} \\
\hline & Ayrı & 16 & 18.44 & 4.40 & & & \\
\hline \multirow{2}{*}{ SD } & Birlikte & 583 & 14.79 & 4.20 & \multirow{2}{*}{1.21} & \multirow{2}{*}{597} & \multirow{2}{*}{.226} \\
\hline & Ayrı & 16 & 13.50 & 4.05 & & & \\
\hline \multirow{2}{*}{ SK } & Birlikte & 583 & 16.31 & 3.17 & \multirow{2}{*}{-2.82} & \multirow{2}{*}{597} & \multirow{2}{*}{$.005^{* *}$} \\
\hline & Ayrı & 16 & 18.56 & 2.42 & & & \\
\hline \multirow{2}{*}{ SBTP } & Birlikte & 583 & 95.66 & 11.05 & \multirow{2}{*}{-2.41} & \multirow{2}{*}{597} & \multirow{2}{*}{$.016 *$} \\
\hline & Ayrı & 16 & 102.37 & 8.94 & & & \\
\hline
\end{tabular}

Not: $p<.05^{*}, p<.01^{* *}$.

Tablo 5'te görüldüğü gibi sosyal anlatımcılık $[t(597)=-2.44 ; p<.05]$, sosyal kontrol $[t(597)=-2.82$; $p<.01]$ ve SBE-KF toplam puanında [t(597)=-2.41; $p<.05]$ öğretmen adaylarının anne-baba birlikteliğine göre anlamlı fark olduğu ortaya çıkmıştır. Bu fark ortalama puanlar açısından, sosyal anlatımcılık $(\bar{X}=18.44)$, sosyal kontrol $(\bar{X}=18.56)$ boyutlarında ve SBE-KF toplam puanında $(\bar{X}=102.37)$ anne-babanın ayrı olması lehine olarak belirlenmiştir. Duyuşsal anlatımcılık $(\bar{X}=17.44)$, duyuşsal duyarlık $(\bar{X}=19.56)$, duyuşsal kontrol $(\bar{X}=14.87)$ ve sosyal duyarlık $(\bar{X}=14.79)$ alt boyutlarında ise anlamlı bir farklılığın olmadığı görülmektedir.

\section{SONUÇ, TARTIŞMA VE ÖNERILER}

\subsection{Sonuç ve Tartışma}

Öğretmen adaylarının sosyal beceri düzeyleri ile cinsiyetleri arasındaki farkı inceleyen bulgulara göre duyuşsal anlatımclık alt boyutunda kadınların lehine; duyuşsal kontrol alt boyutunda ve sosyal beceri toplam puanında erkeklerin lehine anlamlı farklılık ortaya çıkmıştır (Tablo 1). Duyuşsal anlatımcılık alt boyutunda kadınların erkeklere göre daha fazla sosyal beceri göstermesi, kadınların duygusal açıdan kendilerini daha iyi ifade etmeleri ile açıklanabilir. Duyuşsal kontrol boyutunda erkeklerin kadınlara göre sosyal becerilerinin yüksek olması ise erkeklerin duyguları düzenleme ve kontrol becerilerinin daha yüksek olduğunu gösterir. Ayrıca, erkekler duygularını daha çok saklayabilmektedir (Deniz, 2002: 163). Avşar vd. (2007: 203); Çilingir (2006: 53); Deniz vd. (2005: 24); Kalafat (2006: 64); Kırılmazkaya (2010: 25); Koç-Telli (2010: 50); Şahin ve Yeşil (2010: 1203); Zengin vd. (2012: 659) yaptıkları çalışmalarda duyuşsal anlatımcılık alt boyutunda kadınların lehine; duyuşsal kontrol alt boyutunda ise erkeklerin lehine sosyal becerilerin daha yüksek olduğu yönündeki bulguları, bu çalışmanın bulgularıyla örtüşmektedir.

Öğretmen adaylarının sosyal beceri düzeylerinin duyuşsal kontrol, sosyal anlatımcılık, sosyal kontrol alt boyutlarında ve sosyal beceri toplam puanında öğrenim gördükleri FEN ve SINIF eğitimi lisans programlarında, RPD ve OKÖ bölümlerine göre anlamlı olarak farklılaştığı görülmüştür (Tablo 2). Şenol (2015: 43), sosyal duyarlılık alt boyutunda sınıf öğretmenliği adaylarının lehine olmak 
üzere bölümler ile sosyal beceri arasında anlamlı bir fark olduğunu ifade etmiştir. OKÖ ve RPD bölümlerindeki öğretmen adaylarının, sosyal becerileri ile ilişkili olan iletişim, sosyal ve psikoloji alanlarında daha yetkin olmaları beklenir. Bu sonuç, öğretmen adaylarının alımında daha kapsamlı testlerin yapılmasının önemine işaret etmektedir. Alanyazındaki birçok çalışmada araştırmacılar bölümlerin sosyal beceri düzeyini etkilediğini belirlemişlerdir (Emran-Özbulak ve Bulut-Serin, 2011: 308; Girgin vd., 2011; Özçep, 2007: 71; Ş. Akpınar, 2014: 65; Şenol ve Türkçapar, 2016: 449).

Araştırmada öğretmen adaylarının sosyal beceri düzeylerinin sınıf değişkenine göre sosyal anlatımcılık alt boyutunda 2. sınıf ve 3. sınıf arasında 3. sınıfın lehine olmak üzere anlamlı olarak farklılaştı̆̆ı belirlenmiştir (Tablo 3). Yaşar-Ekici'nin (2017:25) çalışmasında da sosyal anlatımcılık alt boyutunun 2. sınıf ve 3. sınıf arasında 3. sınıfın lehine olmak üzere farklılaşması bu araştırmanın bulgularıyla örtüştügünü göstermektedir. Alanyazındaki birçok çalışmada da bu araştırmadaki sonuçlara benzer şekilde sınıf değişkeninin sosyal beceriler üzerinde bir etkisinin olduğu görülmektedir (Avşar vd., 2007: 204; Dicle, 2006: 129; Kalafat, 2006: 69; S. Akpınar vd., 2012: 541; 2015: 83; Şenol, 2015: 43; Türkan vd., 2017: 2416).

Öğretmen adaylarının sosyal beceri düzeyleri ile aile geliri değişkeni arasında SBE-KF ölçeğinin duyuşsal duyarlık ve sosyal anlatımclık alt boyutları ile sosyal beceri toplam puanının genel olarak $5000 \mathrm{TL}$ ve fazlası gelire sahip olan ailelerin lehine olmak üzere anlamlı olarak farklılaştığı belirlenmiştir (Tablo 4). Bu sonuç, yaşam kalitesinin artmasını sağlayan aile gelirinin yükselmesiyle öğretmen adaylarının sosyal becerileri düzeylerinin de artacağı şeklinde yorumlanabilir. Yapılan bazı çalışmalarda da aile gelirinin sosyal beceri üzerinde bir etkisinin olduğu belirlenmiştir (Avşar vd., 2007: 203; Bacanlı ve Erdoğan, 2003: 365; Çilingir, 2006: 62; S. Akpınar vd., 2012: 541; Seven, 2007: 491; Şahin ve Yeşil, 2010: 1207; Tosuntaş-Karakuş, 2006: 136; Uçar, 2010: 91; Yaşar-Ekici, 2017: 31; YazıcI, 2016: 306).

Öğretmen adaylarının sosyal becerilerinin SBE-KF ölçeğinin sosyal anlatımcılık ve sosyal kontrol alt boyutları ile sosyal beceri toplam puanının anne-babası ayrı olanların anne-babası birlikte olanlara göre daha fazla sosyal beceri düzeyine sahip oldukları görülmektedir (Tablo 5). Anne-babası ayrı olanların daha düşük sosyal beceri düzeyine sahip olmaları beklenirken; bu araştırmadan elde edilen sonucun, alt değişkenlerde yer alan örneklem sayısının birbirinden çok farklı olmasından kaynaklandığı söylenebilir. Bu çalışmadaki bulguların aksine, Tosuntaş-Karakuş (2006: 128), çalışmasında anne babası ayrı olanların daha az sosyal beceri gösterdiklerini tespit etmiştir.

Öğretmen adaylarının sosyal beceri düzeyleri ile; cinsiyet, bölüm, sınıf, aile geliri, anne-baba birlikteliği değişkenleri arasında anlamlı bir farklııık ortaya çıkmıştır. Öğretmen adaylarının sosyal beceri düzeyleri ile; kardeş sayısı, doğum sırası, anne-baba yaşam durumu, anne-baba öz-üvey olma, anne-baba eğitim düzeyi değişkenleri arasında anlamlı bir farklılı̆ın olmadığı sonucuna varılmıştır. Aile gelir düzeyinin ve ebeveynlerin eğitim seviyesinin sosyal becerilerin gelişiminde önemli bir faktör olduğu gözlenmiştir. Sosyal beceriler konusunda farkındalık sahibi öğretmen adayları, kalkınmada önemli rol oynayacak olan yeni nesiller için bir kazanç olacaktır. Öğrencilerini eğitmeden ve geliştirmeden önce öğretmen adayları gerekli donanım, bilgi ve becerileri edinmiş olmalıdır. Öğretmen adaylarının sosyal becerileri kazanmış olması öğrencileri ile sağlıklı ilişkiler kurmasına, problemleri büyümeden çözmesine, öğrencilerini daha iyi anlamasına olanak tanıyacağı söylenebilir.

\section{2 Öneriler}

Öğretmen adaylarının sosyal becerileri, bölümlerine göre karşılaştırıldığında RPD ve OKÖ gibi yüksek puanlarla üniversiteyi kazanan öğrencilerin sosyal beceri puanlarının diğer bölümlere göre düşük olduğu belirlenmiş̧tir. Bu bağlamda, üniversite öğrencisi adaylarını belirlerken sertifika, kurs vb. eğitimler yönünden donanımlı olup olmadıklarına bakılarak öğrenci alımı yapılabilir. Öğretmen adaylarının öğretmenliğe geçişi sadece bir sınavla değil; çocuğun gelişimine katkı sağlayacak şekilde kişilik, sosyallik ve eğitsel yönden becerilerinin ölçülmesiyle olmalıdır. Sosyal beceri gelişiminin devam ettiği üniversite ortamında da öğretmen adaylarına lisans dönemleri boyunca sosyal becerilerini artıracak uygulamalar yürütülebilir. 


\section{Kaynakça}

Akpınar, S., Temel, V. ve Nas, K. (2012). An Exploration of Candidate Teachers' Social Skills Levels: Age, Gender and Other Differences. Ovidius University Annals, 12(2), 538-543.

Akpınar, S., Akpınar, Ö., Nas, K., Temel, V. ve Birol, S. Ş. (2015). Beden Eğitimi ve Spor Yüksekokulunda Okuyan Öğrencilerinin Bazı Değişkenler Açısından Sosyal Beceri Düzeylerinin Incelenmesi. Karamanoğlu Mehmetbey Üniversitesi Sosyal ve Ekonomik Araştırmalar Dergisi, 17(28), 80-84.

Akpınar, Ş. (2014). Öğretmen Adaylarının Problem Çözme ve Sosyal Becerilerinin Incelenmesi. Yüksek lisans tezi. Kahramanmaraş Sütçü İmam Üniversitesi, Sosyal Bilimler Enstitüsü, Kahramanmaraş.

Anthony, C. J., DiPerna, J. C. ve Lei, P. W. (2016). Maximizing measurement efficiency of behavior rating scales using Item Response Theory: An example with the Social Skills Improvement System-Teacher Rating Scale. Journal of School Psychology, 55, 57-69.

Avşar, Z. ve Öztürk-Kuter, F. (2007). Beden Eğitimi ve Spor Bölümü Öğrencilerinin Sosyal Beceri Düzeylerinin Belirlenmesi (Uludağ Üniversitesi Örneği). Eğitimde Kuram ve Uygulama, 3(2), 197206.

Bacanlı, H. (2014). Sosyal Beceri Eğitimi. (5. Baskı). Ankara: Pegem Akademi.

Bacanlı, H. ve Erdoğan, F. (2003). Matson Çocuklarda Sosyal Becerileri Değerlendirme Ölçeğinin (MESSY) Türkçeye Uyarlanması. Kuram ve Uygulamada Eğitim Bilimleri, 3(2), 351-379.

Berry, D. ve O'Connor, E. (2010). Behavioral risk, teacher-child relationships, and social skill development across middle childhood: A child-by-environment analysis of change. Journal of Applied Developmental Psychology, 31(1), 1-14.

Burger, J. M. (2006). Kişilik (1. Baskı). Çev., Erguvan Sarıoğlu. İstanbul: Kaknüs Yayınları.

Burke, R. W. (2002). Social and Emotional Education in The Classroom. Kapa Delta Pi Record, 38(3), 108-111.

Burke, T. J., Woszidlo, A. ve Segrin, C. (2012). Social Skills, Family Conflict, and Loneliness in Families. Communication Reports, 25(2), 75-87.

Büyüköztürk, Ş. (2013). Sosyal Bilimler İçin Veri Analizi El Kitabı Istatistik, Araştırma Deseni SPSS Uygulamaları Ve Yorum (18. Baskı). Ankara: Pegem Akademi.

Büyüköztürk, Ş., Kılıç-Çakmak, E., Akgün, Ö. E., Karadeniz, Ş. ve Demirel, F. (2013). Bilimsel Araştırma Yöntemleri [Research Methods]. (15. Baskı). Ankara: Pegem Akademi.

Çilingir, A. (2006). Fen Lisesi Ile Genel Lise Öğrencilerinin Sosyal Beceri ve Problem Çözme Becerilerinin Karşıllaştırılması. Yüksek lisans tezi. Atatürk Üniversitesi, Sosyal Bilimler Enstitüsü, Erzurum.

Deniz, M. E. (2002). Üniversite Öğrencilerinin Karar Verme Stratejileri ve Sosyal Beceri Düzeylerinin TABaskın Ben Durumları ve Bazı Özlük Niteliklere Göre Karşılaştırmalı Olarak Incelenmesi. Doktora tezi. Selçuk Üniversitesi, Sosyal Bilimler Enstitüsü, Konya.

Deniz, M. E., Hamarta, E. ve Arı, R. (2005). An Investigation of Social Skills and Loneliness Levels of University Students with Respect to Their Attachment Styles in a Sample Of Turkish Students. Social Behavior and Personality: An International Journal, 33(1), 19-32.

Dereli-Iman, E. (2014). Değerler Eğitimi Programının 5-6 Yaş Çocukların Sosyal Gelişimine Etkisi: Sosyal Beceri, Psiko-Sosyal Gelişim ve Sosyal Problem Çözme Becerisi. Kuram ve Uygulamada Eğitim Bilimleri, 14(1), 249-268.

Dicle, A. N. (2006). Üniversite Öğrencilerinin Sosyal Beceri Düzeylerinin Duygusal Zeka Düzeyleri ve Bazı Kişisel Özelliklerine Göre Incelenmesi. Yüksek lisans tezi. Ondokuz Mayıs Üniversitesi, Sosyal Bilimler Enstitüsü, Samsun. 
Dilekmen, M. (2008). Etkili Eğitim İçin Etkili Öğretmenlik. Atatürk Üniversitesi Sosyal Bilimler Enstitüsü Dergisi, 12(2), 213-221.

Dökmen, Ü. (2001). Iletişim Çatışmaları ve Empati. İstanbul: Sistem Yayınevi.

Durualp, E. (2014). Ergenlerin Sosyal Duygusal Öğrenme Becerilerinin Cinsiyet ve Sınıfa Göre Incelenmesi. The Journal of Academic Social Science Studies, 26(2), 13-25.

Durualp, E. ve Aral, N. (2010). Altı Yaşındaki Çocukların Sosyal Becerilerine Oyun Temelli Sosyal Beceri Eğitiminin Etkisinin Incelenmesi. Hacettepe Üniversitesi Ĕgitim Fakültesi Dergisi, 39, 160-172.

Emran-Özbulak, B. ve Bulut-Serin, N. (2011). Okul Psikolojik Danışmanlarının Problem Çözme ve Sosyal Beceri Düzeylerinin İncelenmesi. Hacettepe Üniversitesi Eğitim Fakültesi Dergisi, 41, 302312.

Ertuğrul, H. (2011). Her Yönüyle Örnek Öğretmen. (9. Baskı). İstanbul: Nesil Basım Yayın.

Girgin, G., Çetingöz, D. ve Ekinci-Vural, D. (2011). Öğretmen Adaylarının Sosyal Beceri Düzeylerinin İncelenmesi. Kuramsal Eğitimbilim, 4(1), 38-49.

Goleman, D. (2016). Sosyal Zeka (Insan Ilişkilerinin Yeni Bilimi). İstanbul: Varlık Yayınevi.

Gresham, F. M. (2016). Social Skills Assessment and Intervention for Children and Youth. Cambridge Journal of Education, 46(3), 319-332.

Griffith, S., Arnold, D., Voegler-Lee, M. E. ve Kupersmidt, J. (2016). Individual Characteristics, Family Factors, and Classroom Experiences as Predictors of Low-Income Kindergarteners' Social Skills. Journal of Educational and Developmental Psychology, 6(1), 59-76.

Gülay, H. ve Akman, B. (2009). Okul Öncesi Dönemde Sosyal Beceriler. Ankara: Pegem Akademi Yayınları.

Jennings, P. A. ve Greenberg, M. T. (2009). The Prosocial Classroom: Teacher Social and Emotional Competence in Relation to Student and Classroom Outcomes. Review of Educational Research, 79(1), 491-525.

Johns, B. H., Crowley, E. P. ve Guetzloe, E. (2005). The Central Role of Teaching Social Skills. Focus on Exceptional Children, 37(8), 1-8.

Kalafat, T. (2006). Üniversite Öğrencilerinin Beden Memnuniyeti Düzeyleri ile Soysal Beceri Düzeyleri Arasındaki ilişkinin Karşılaştırmalı Olarak incelenmesi (Çanakkale ili Örneği). Yüksek lisans tezi. Çanakkale Onsekiz Mart Üniversitesi, Sosyal Bilimler Enstitüsü, Çanakkale.

Karacaoğlu, Ö. C. (2008). Öğretmenlerin Yeterlilik Algıları. Yüzüncü Yıl Üniversitesi Eğitim Fakültesi Dergisi, 5(1), 70-97.

Kırılmazkaya, G. (2010). ilköğretim Fen Bilgisi ve Sınıf Öğretmen Adaylarının Problem Çözme Becerileri ve Sosyal Becerilerinin Karşılaştırılması. Yüksek lisans tezi. Fırat Üniversitesi, Fen Bilimleri Enstitüsü, Elazı̆̆.

Koç-Telli, M. (2010). Mersin Üniversitesi Öğrencilerinin Sosyal Beceri Düzeyleri ile Yetkinlik Beklentilerinin incelenmesi. Yüksek lisans tezi. Mersin Üniversitesi, Sosyal Bilimler Enstitüsü, Mersin.

Koydemir, S. (2006). Üniversite Öğrencilerinde Utangaçlı̆ı̆ Yordayıcıları: Bir Benlik Sunumu Modelinin incelenmesi. Yüksek lisans tezi. Orta Doğu Teknik Üniversitesi, Sosyal Bilimler Enstitüsü, Ankara.

Kozağaç, Z. B. (2015). Matematik Bölümü Öğretmen Adaylarının Çoklu Zeka Alanlarının Belirlenmesi ve Sosyal Becerileri ile Öğretmenlik Mesleğine ilişkin Tutumlarının Incelenmesi. Yüksek lisans tezi. Adnan Menderes Üniversitesi, Sosyal Bilimler Enstitüsü, Aydın.

Meadan, H. ve Monda-Amaya, L. (2008). Collaboration to Promote Social Competence for Students with Mild Disabilities in The General Classroom: A Structure for Providing Social Support. Intervention in School and Clinic, 43(3), 158-167.

Okumuş, M. (2011). Öğretmenlerde Meslek Tatmini Ve Iş Stresi. İstanbul: Ark Kitap. 
Özabacı, N. (2004). Öğretmen Adaylarının Duygusal Zeka ve Sosyal Beceri Düzeyleri Arasındaki Iliş̧kinin Incelenmesi. 8. Eğitim Bilimleri Kurultayı, 6-9 Temmuz, Malatya.

Özçep, C. (2007). Ilköğretimde Görev Yapan Beden Eğitimi ve Sınıf Öğretmenlerinin Sosyal Beceri Düzeylerinin Çeşitli Değişkenler Açısından Karşılaştırılması. Yüksek lisans tezi. Abant İzzet Baysal Üniversitesi, Sosyal Bilimler Enstitüsü, Bolu.

Riggio, R. (1986). Assessment of Basic Social Skills. Journal of Personality and Social Psychology, 51(3): 649-660.

Riggio, R. E. ve Reichard, R. J. (2008). The Emotional and Social Intelligences of Effective Leadership: An Emotional and Social Skill Approach. Journal of Managerial Psychology, 23(2), 169-185.

Riney, S. S. ve Bullock, L. M. (2012). Teachers' Perspectives on Student Problematic Behavior and Social Skills. Emotional and Behavioural Difficulties, 17(2), 195-211.

Seven, S. (2007). Ailesel Faktörlerin Altı Yaş Çocuklarının Sosyal Davranış Problemlerine Etkisi. Kuram ve Uygulamada Eğitim Yönetimi, 51(51), 477-499.

Seven, S. ve Yoldaş, C. (2007). Sınıf Öğretmeni Adaylarının Sosyal Beceri Düzeylerinin İncelenmesi. Yüzüncü Yıl Üniversitesi Eğitim Fakültesi Dergisi, 4(1), 1-18.

Tanrıöğen, A. (2011). Metodoloji. Bilimsel Araştırma Yöntemleri (109-130). Ankara: Anı Yayıncılık.

Şahin, B. (2011). Metodoloji. Abdurrahman Tanrı̈ğen (Ed.), Bilimsel araştırma yöntemleri içinde (s.109-130). (2. Baskı). Ankara: Anı Yayıncılık.

Şahin, C. ve Yeşil, R. (2010). Sınıf Öğretmenliği Aday Öğretmenlerinin Sosyal Beceri ve Empatik Eğilim Düzeyleri (AEÜ Eğitim Fakültesi Örneği). E-Journal of New World Sciences Academy, 5(3), 1197-1212.

Şahin, E. E. ve Gizir, C. A. (2013). Kişilerarası Yetkinlik Ölçeği-Kısa Formu: Geçerlik ve Güvenirlik Çalışmaları. Mersin Üniversitesi Eğitim Fakültesi Dergisi, 9(3), 144-158.

Şenol, E. (2015). Beden Eğitimi ve Spor Öğretmenliği ile Eğitim Fakültesi Sınıf Öğretmenlerinin Sosyal Beceri Düzeylerinin incelenmesi. Yüksek lisans tezi. Kahramanmaraş Sütçü İmam Üniversitesi, Sağlık Bilimleri Enstitüsü, Kahramanmaraş.

Şenol, E. ve Türkçapar, Ü. (2016). Üniversite Öğrencilerinin Sosyal Beceri Düzeylerinin İncelenmesi. Mehmet Akif Ersoy Üniversitesi Eğitim Fakültesi Dergisi, 1(40), 445-456.

Tepeli, K. ve Arı, R. (2011). Okul Öncesi Eğitim Öğretmeni ve Öğretmen Adaylarının İletişim ve Sosyal Becerilerinin Karşılaştırmalı Olarak Incelenmesi. Selçuk Üniversitesi Sosyal Bilimler Enstitüsü Dergisi, 26, 385-394.

Tosuntaş-Karakuş, F. (2006). Ergenlerde Algılanan Duygusal istismar ile Sosyal Beceri Arasındaki ilişki. Yüksek lisans tezi. Marmara Üniversitesi, Eğitim Bilimleri Enstitüsü, İstanbul.

Türkan, E., Aydoğan, Y. ve Sezer, T. (2017). Okul Öncesi Öğretmen Adaylarının Sosyal Becerilerinin Incelenmesi. Kastamonu Eğitim Dergisi, 24(5), 2409-2424.

Tynjälä, P., Virtanen, A., Klemola, U., Kostiainen, E. ve Rasku-Puttonen, H. (2016). Developing Social Competence and Other Generic Skills in Teacher Education: Applying the Model of Integrative Pedagogy. European Journal of Teacher Education, 39(3), 368-387.

Uçar, N. Y. (2010). Okul Öncesi Öğretmenlerinin Sosyal Becerilerini Etkileyen Faktörler. Yüksek lisans tezi. Selçuk Üniversitesi, Eğitim Bilimleri Enstitüsü, Konya.

Väyrynen, S., Kesälahti, E., Pynninen, T., Siivola, J., Flotskaya, N., Bulanova, S., vd. (2016). Finnish and Russian Teachers Supporting the Development of Social Skills. European Journal of Teacher Education, 39(4), 437-451.

Villares, E., Brigman, G. ve Peluso, P. (2008). Ready to Learn: An Evidence-Based Individual Psychology Linked Curriculum for Prekindergarten through First Grade. Journal of Individual Psychology, 64(4), 386-402. 
Yaşar-Ekici, F. (2017). Examination of Preservice Preschool Teachers' Level of Problem Solving and Social Skills. International Journal of Social Sciences and Education Research, 3(1), 16-38.

Yazıcı, T. (2016). Müzik Öğretmeni Adaylarının Problem Çözme ve Sosyal Becerileri. Kastamonu Eğitim Dergisi, 25(1), 299-314.

Yüksel, G. (1997). Sosyal Beceri Eğitiminin Üniversite Öğrencilerinin Sosyal Beceri Düzeyine Etkisi. Doktora tezi. Gazi Üniversitesi, Sosyal Bilimler Enstitüsü, Ankara.

Yüksel, G. (2001). Öğretmenlerin Sahip Olmaları Gereken Davranış Olarak Sosyal Beceri. Milli Ĕğtim Dergisi, 150.

Zengin, F., Kırılmazkaya, G. ve Zengin, R. (2012). Illköğretim Fen Bilgisi ve Sınıf Öğretmen Adaylarının Sosyal Becerilerinin Karşılaştırılması. E-Journal of New World Sciences Academy, 7(2), 656-667. 


\section{Extended Summary}

For the healthy development of children who spent most of their developmental period in school, the teacher should also give importance to the holistic development of children. When preservice teachers start their professional career, they need to help the children in every way, not only by giving them education but also by getting to know them, being conscious of their developmental characteristics and being aware of the problems that children are experiencing. Preservice teachers who will be aware of the factors that play a role in healthy development by setting social skills will also be able to undertake an important task in order to raise a healthy generation. It is understood from studies done that the qualifications of teachers and prospective teachers who have a great role in gaining social skills of children (Anthony, et al., 2016; Gresham, 2016; Griffith, et al., 2016; Kozağaç, 2015; Şenol \& Türkçapar, 2016; Türkan et al., 2017; Tynjälä, et al., 2016; Väyrynen et al., 2016; Yaşar-Ekici, 2017; Yazıcı, 2016). Given the positive effects of atmospherics in the classroom, it is important to determine the variables that affect the social skills of prospective teachers (Seven and Yoldaş, 2007). It is expected that this study will give a different aspect to the literature and the more awareness of teacher candidates about social skills. The general aim of this study was to determine the variables of gender, department, class level, family income level, number of siblings, order of birth, parents' life situation, parents' unity, parents' self- Social skills.

Because this research aims to determine some variables that predict social skill levels of preservice teachers, descriptive survey model is used in quantitative research methods. The survey model is preferred in order to determine the extent to which the desired characteristic is to be measured, which allows studying with larger samples than other study designs (Büyüköztürk, Kılıç-Çakmak, Akgün, Karadeniz and Demirel, 2013). There are 628 preservice teachers who are in the first, second, third and fourth classes of science education, classroom education, pre-school education (PSE) and guidancepsychological counseling (GPC) sections of the education faculty of Amasya University in the academic year 2016-2017. In this research, Social Skill Inventory Short Form (SBE-SF) was used to determine social skills levels in adulthood and the personal information form was used to determine demographic characteristics of preservice teachers. Independent sample $t$ test, frequency, percentage distributions, one-way ANOVA were used for normal distributions (Büyüköztürk, 2013).

There was a significant difference between the subscales of emotional expression and emotional control and the gender of preservice teachers in SBE-SF total score. It is seen that there is a significant difference between SBE-SF total scores with the subscales of emotional control, social expression and social control. It shows that there is a meaningful difference statistically in favor of the 3rd grade in the social expression sub-dimension with the class levels of the preservice teachers. For the affective expression and social sensitivity sub-dimension of SBE-SF in favor of family income variable between 4001-5000 TL; In favor of family income variable between 2001-3000 TL in the affective sensitivity sub-dimension; It is observed that social skills average scores for affective control, social expression, social control and SBESF total score of $5001 \mathrm{TL}$ and above are higher than other income levels. In this research, with the social skill levels of the preservice teachers; the number of siblings, the order of birth, the life status of the parents, the togetherness of the parents, and the level of parental education did not differ significantly.

The fact that women have more social skills than men in the emotional expression sub-dimension can be explained by the fact that women express themselves better emotionally. The higher the social skills of men compared to women in the dimension of emotional control, the higher the men's emotional regulation and control skills are (Kırılmazkaya, 2010; Koç-Telli, 2010; Şahin and Yeşil, 2010; Zengin et al., 2012). In addition, men can hide their feelings more (Deniz, 2002). There is a significant difference between departments and social skills in favor of classroom preservice teachers in the social sensitivity subscale (Girgin et al., 2011; Ş. Akpınar, 2014; Şenol and Türkçapar, 2016). It is expected that the preservice teachers in PSE and GPC departments should be more competent in the fields of communication, social and psychology related to their social skills. This result indicates the importance of more comprehensive testing of preservice teachers. According to results of this research, it can be deduced that when preservice teachers move to upper classes, they are more socially equipped with increasing age and that they are a factor that increases the social skills of their education (S. Akpınar et al., 2015; Şenol, 2015; Türkan et al., 2017). It was determined that between the social skill levels of the preservice teachers and the family income variable had significant differences in emotional sensitivity 
and social expression subscales (Table 4). This result can be interpreted as the increase of the family income which increases the quality of life and the social skills of the preservice teachers will increase (Yaşar-Ekici, 2017; Yazıcı, 2016).

With the social skill levels of the preservice teachers; gender, department, class, family income, motherfather variables have difference meaningfully. The number of siblings, the order of birth, the life style of the parents, the togetherness of the parents, and the educational level of the parents did not differ significantly. It has been observed that the level of family income and the educational level of parents are important factors in the development of social skills. In the university environment where the development of social skills continues, it is possible to carry out applications that will increase social skills during the undergraduate periods for the prospective teachers. 